\title{
Nitrogen partitioning and milk production of dairy cows grazing simple and diverse pastures
}

\author{
V. K. Totty, ${ }^{*}$ S. L. Greenwood, ${ }^{*} \dagger$ R. H. Bryant, ${ }^{*}$ and G. R. Edwards ${ }^{* 1}$ \\ *Department of Agricultural Sciences, Lincoln University, Lincoln, New Zealand 7647 \\ †Department of Animal Science, University of Vermont, Burlington 05405
}

\begin{abstract}
Research was conducted to examine the effects of a diverse pasture mix on dry matter intake, milk yield, and $\mathrm{N}$ partitioning of lactating dairy cows. A pasture containing only ryegrass and white clover $(\mathrm{RG})$, or highsugar ryegrass and white clover (HS), was compared with a diverse pasture mix (HSD) including chicory, plantain, lotus, high-sugar ryegrass, and white clover. The experiment was conducted over a $10-\mathrm{d}$ period using 3 groups of 12 cows in late lactation. No difference was observed in dry matter (14.3 $\mathrm{kg}$ of dry matter/ cow per day) or $\mathrm{N}$ (583 g of $\mathrm{N} /$ cow per day) intake between treatments. The cows grazing the HSD pasture had an increased milk yield $(16.9 \mathrm{~kg} / \mathrm{d})$ compared with those grazing the simple RG and HS pastures (15.2 and $14.7 \mathrm{~kg} / \mathrm{d}$, respectively). However, no differences were observed in milk solids yield for the 3 treatments. A tendency toward greater milk protein yields in the HSD group resulted in improved $\mathrm{N}$ use efficiency for milk of $20.4 \%$ from the cows fed HSD, compared with 17.8 and $16.7 \%$ from cows in the RG and HS treatments, respectively. Urinary $\mathrm{N}$ excretion was lower from the cows fed HSD, at $353.8 \mathrm{~g} / \mathrm{d}$, compared with 438.3 and $426.6 \mathrm{~g} / \mathrm{d}$ for cows fed RG and HS, respectively. These results suggest that the use of pastures containing chicory, lotus, and plantain can contribute to the goal of reducing $\mathrm{N}$ losses from cows in late lactation.
\end{abstract}

Key words: nitrogen partitioning, milk yield, pasture species, dairy cow

\section{INTRODUCTION}

The environmental impact of dairy farming has been a topic of interest because of its contribution to $\mathrm{CH}_{4}$, $\mathrm{CO}_{2}$, and $\mathrm{N}$ emissions. Urinary $\mathrm{N}$ excreted by dairy cattle is one of the New Zealand dairy industry's more

Received March 4, 2012

Accepted September 22, 2012.

${ }^{1}$ Corresponding author: grant.edwards@lincoln.ac.nz significant environmental polluters because nitrate $\left(\mathrm{NO}_{3}{ }^{-}\right)$derived from urinary $\mathrm{N}$ contributes to ground and surface water contamination (Di and Cameron, 2002). High-quality temperate forages, such as perennial ryegrass and white clover pastures, are of high nutritive value, with $\mathrm{ME}$ concentrations typically greater than 11.5 MJ of $\mathrm{ME} / \mathrm{kg}$ of $\mathrm{DM}$ and a CP content of up to $30 \%$ (Waghorn et al., 2007), which occur most typically in autumn. This high-protein diet ultimately provides an excess of $\mathrm{N}$ relative to animal requirements, and excretion of excess $\mathrm{N}$ results in both a metabolic cost to the animal and increased environmental pollution.

Urea is the predominant N-containing compound in the urine. After deposition, urea is rapidly hydrolyzed to $\mathrm{NO}_{3}{ }^{-}$in the soil (Haynes and Williams, 1993), where it is readily leached, particularly during periods of high rainfall. Large losses of ammonia also occur by volatilization after a urination event as well as losses of $\mathrm{N}_{2} \mathrm{O}$ during the denitrification process. Fecal $\mathrm{N}$ is present in a more stable form and therefore takes longer to break down than urine N (Powell et al., 2009). Ultimately, because of this slower leaching rate, an increased fecal:urinary $\mathrm{N}$ ratio is seen as desirable from an environmental perspective.

Options for reducing urinary $\mathrm{N}$ excretion in grazing systems include using ryegrass cultivars with a lower CP concentration (Miller et al., 2001; Moorby et al., 2006) or using plant species with higher RUP, which divert the dietary $\mathrm{N}$ away from urine (Woodward et al., 2009). Alternative forages may provide opportunities for altering $\mathrm{N}$ partitioning within the animal. Alternative pasture species that can be incorporated into pasture mixes include high-sugar ryegrasses, chicory, plantain, and the lotus genus. Newly developed grasses, such as high-sugar ryegrass, have been bred to contain a higher content of water-soluble carbohydrates (WSC) and have been proposed as another method to increase the efficiency of $\mathrm{N}$ use (Edwards et al., 2007a). This is due to an improved rumen supply and synchrony of energy with $\mathrm{CP}$ to increase microbial protein synthesis. Some alternative forages, such as lotus, also contain condensed tannins (CT). Condensed tannins are phenolic 
compounds found in plant cells that bind to dietary protein, making it unavailable for animal absorption (Waghorn et al., 1994; Barry and McNabb, 1999) and thus increasing the fecal:urinary $\mathrm{N}$ ratio.

The objectives of this experiment were to examine the changes in DMI, milk yield, and urinary N excretion that result from a change in the pasture species fed to dairy cows during late lactation. It was hypothesized that the high-sugar grass and the diverse pasture mix would increase DMI and milk yield and reduce the amount of $\mathrm{N}$ excreted in urine.

\section{MATERIALS AND METHODS}

All procedures were approved by the Lincoln University Animal Ethics Committee. Thirty-six Friesian $\times$ Jersey crossbred multiparous cows in late lactation were used in a randomized complete block design, with 12 cows in each treatment. Cows were blocked for age (4 $\pm 2 \mathrm{yr}$ of age), BW $(464 \pm 50 \mathrm{~kg})$, and milk production $(13.8 \pm 2.7 \mathrm{~kg} / \mathrm{d})$. Cows were, on average, $190 \pm$ 19 DIM at the beginning of the trial. Before the start of the trial, cows all rotationally grazed on a ryegrass + white clover pasture together.

\section{Diet}

Approximately 4.5 ha of pasture located at the Lincoln University Research Dairy Farm in Canterbury, New Zealand $\left(43^{\circ} 38^{\prime} \mathrm{S}, 172^{\circ} 27^{\prime} \mathrm{E}\right)$, was used to conduct a 10-d grazing trial (5-d acclimation period $+5-\mathrm{d}$ experimental period) between March 22 and April 2, 2010. The cows were milked twice daily (approximately 0700 and $1500 \mathrm{~h}$ ) and given a new pasture allowance after each afternoon milking. Permanent fences separated the paddocks, whereas electric fences were used to separate daily pasture allocations. Cows were offered an estimated pasture allocation of $16 \mathrm{~kg}$ of $\mathrm{DM} /$ cow per day above a postgrazing pasture residual of 1,400 $\mathrm{kg}$ of $\mathrm{DM} /$ ha. Plastic water troughs were moved daily into the grazed area to allow ad libitum access to water.

Cows were offered a dietary treatment of (1) perennial ryegrass (Lolium perenne) + white clover (Trifolium repens; RG), (2) high-sugar perennial ryegrass (L. perenne) + white clover (HS), or (3) high-sugar perennial ryegrass + white clover + chicory $($ Cichorium intybus) + plantain (Plantago lanceolata) + lotus (Lotus pedunculatus; HSD). The pasture was sown in three 0.5-ha plots for each treatment in a randomized design. All plots were irrigated by center-pivot irrigation. All plots were fertilized with $50 \mathrm{~kg}$ of $\mathrm{N} / \mathrm{ha}$ as urea $28 \mathrm{~d}$ before the study commenced.

\section{Intake Measurements}

Pre- and postgrazing pasture mass was determined by a plate meter (PM; Jenquip, Feilding, New Zealand), collecting 50 measurements in each area allocated to cows on a daily basis. The PM was calibrated before the beginning of the experiment by collecting 40 quadrats (each $0.2 \mathrm{~m}^{2} ; 20$ pregrazing and 20 postgrazing quadrats) per pasture treatment after a PM measurement was recorded at the site of the quadrat cut. Separate calibration curves for each pasture treatment were derived by fitting a single line through all data points. The calibration curves used were

$$
\begin{gathered}
\mathrm{RG}(\mathrm{kg} \text { of DM} / \mathrm{ha})=111.5 \mathrm{PM}+334.2, \mathrm{R}^{2}=0.74, \\
\mathrm{HS}(\mathrm{kg} \text { of } \mathrm{DM} / \mathrm{ha})=98.0 \mathrm{PM}+539.2, \mathrm{R}^{2}=0.68, \text { and } \\
\mathrm{HSD}(\mathrm{kg} \text { of DM} / \mathrm{ha})=77.4 \mathrm{PM}+596.3, \mathrm{R}^{2}=0.82 .
\end{gathered}
$$

Mean group DMI was calculated as the difference between pre- and postgrazing pasture yields and the area grazed. Pasture samples were also collected preand postgrazing daily throughout the trial to estimate the DM, botanical, and chemical composition of the different treatment plots (4 samples per day from RG and HS plots; 9 samples per day from HSD plots). To determine DM of the pastures, pre- and postgrazing pasture samples were cut to the approximate grazing height. These samples were then weighed fresh, dried in an oven at $65^{\circ} \mathrm{C}$ for $48 \mathrm{~h}$, and reweighed to ascertain DM. To determine the botanical and chemical composition of the pastures, a second pasture sample was collected at approximately $1400 \mathrm{~h}$ daily before the new pasture allocation was offered. A first subsample was separated into botanical components, and the fresh weight of each component was recorded. The botanical components were then dried in an oven at $65^{\circ} \mathrm{C}$ for $48 \mathrm{~h}$ to ascertain the DM of each component. A second subsample of approximately 100 to $200 \mathrm{~g}$ was taken from the each of the pasture samples and frozen at $-20^{\circ} \mathrm{C}$. This subsample was later freeze-dried and ground to $1 \mathrm{~mm}$ for analysis of nutritive components using nearinfrared spectrophotometry (Foss NIRSystems 5000; FOSS NIRSystems Inc., Laurel, MD). Near-infrared spectrophotometry calibrations for protein (Kjeldahl method), WSC (MAFF, 1986), NDF (Van Soest, 1991) and ADF (method 973.18; AOAC, 1990), and in vitro DM digestibility (Iowerth et al., 1975) were previously derived on perennial ryegrass-based pasture samples, and $\mathrm{R}^{2}$ for predictions were $0.978,0.976,0.985,0.976$, and 0.971 , respectively. 
The CT concentration of the HSD plot was also determined. One pooled sample of freeze-dried HSD was created by combining equal weights of freeze-dried material from HSD pasture samples collected each day during the experimental period. This pooled sample was analyzed for CT concentration using a standard curve created from L. pedunculatus, and analyzed using the methods outlined by Terrill et al. (1992) by a commercial laboratory (Nutrition Laboratory, Massey University, Palmerston North, New Zealand).

\section{Milk Measurements}

Milk yield was measured daily with an automated system (DeLaval Alpro Herd Management System, DeLaval, Tumba, Sweden). Two milk subsamples were collected for every cow at the morning and afternoon milkings on d 0 (baseline), 6, 8, and 10 to determine milk composition and milk urea $\mathrm{N}$ concentration. The subsamples that were used to determine MUN were centrifuged at $4,000 \times g$ for $10 \mathrm{~min}$ at room temperature and refrigerated for $10 \mathrm{~min}$ to allow the fat to solidify on the top and be removed. The skim milk was then pipetted into a clean microcentrifuge tube, chilled, and transported to the laboratory for immediate analysis. Milk urea $\mathrm{N}$ was analyzed commercially (Gribbles Veterinary, Christchurch, New Zealand) on an automated Modular P analyzer (Roche Hitachi, Basel, Switzerland) by an enzymatic assay described previously (Talke and Schubert, 1965). Milk composition was analyzed by the laboratory of the Livestock Improvement Corporation Ltd. (Christchurch, New Zealand) to determine milk fat, protein, and lactose by MilkoScan (Foss Electric, Hillerød, Denmark).

\section{Blood, Urine, and Fecal Measurements}

Immediately after the morning and afternoon milkings on d 0 (baseline), 6, 8 and 10, cows were herded into the veterinary yards for further sample collection. Urine samples were taken midstream after manual stimulation of the vulva, acidified below a $\mathrm{pH}$ of 4.0 with concentrated sulfuric acid to prevent volatilization, and then frozen at $-20^{\circ} \mathrm{C}$ until analysis. Feces samples were collected by rectal stimulation or as the animal defecated and frozen at $-20^{\circ} \mathrm{C}$ until analysis. Blood samples were collected from the coccygeal vein or artery using $10 \mathrm{~mL}$ of sodium heparin and $\mathrm{K}_{3}$ EDTA Vacuette tubes (Greiner Bio-one, Kremsmünster, Austria). Blood samples were placed on ice, and then centrifuged at $3,000 \times g$ at $4^{\circ} \mathrm{C}$ for $15 \mathrm{~min}$, and the separated plasma was stored at $-20^{\circ} \mathrm{C}$ until analysis for creatinine and urea $\mathrm{N}$ concentration.
Urine, feces, and plasma analyses were performed by Lincoln University Analytical Services (Lincoln University, Christchurch, New Zealand). Urine samples were analyzed for percentage of $\mathrm{N}$ and for creatinine, $\mathrm{NH}_{3}$, and urea concentrations. Fecal samples were thawed and subsampled, with 1 subsample being weighed and then dried in an oven at $65^{\circ} \mathrm{C}$ for $48 \mathrm{~h}$ and reweighed to ascertain DM. The other sample was freeze-dried, ground to $1 \mathrm{~mm}$, and analyzed for percentage of $\mathrm{N}$. Urine and fecal $\mathrm{N}$ percentages, as well as urine $\mathrm{NH}_{3}$, urine urea, and plasma urea concentrations, were determined by using a $\mathrm{N}$ analyzer (Vario MAX CN, Elementar Analysensysteme, Hanau, Germany). Creatinine concentration of urine and plasma samples was determined by the Jaffé method (Bartels and Böhmer, 1971; Cobas Mira Plus Analyzer, Roche Hitachi, Basel, Switzerland).

Subsamples of urine collected after the morning and afternoon milkings from individual animals on d 10 were also analyzed for concentration of purine derivatives by using HPLC (Agilent 1100 series, Agilent Technologies, Waldbronn, Germany) as previously described by Czauderna and Kowalczyk (2000), with modifications by George et al. (2006).

\section{Estimation of Microbial N Supply}

Equations used in calculating the estimated microbial N supply outlined below have been described previously (Chen, 1989; Verbic et al., 1990; Chen et al., 1995; Joint FAO/IAEA Division, 2003). To estimate the microbial $\mathrm{N}$ supply based on the urinary excretion of purine derivatives (PD), the PD index was calculated based on total PD [allantoin $(\mathrm{mmol} / \mathrm{L})+$ uric acid $(\mathrm{mmol} / \mathrm{L})]$ as

$$
\begin{gathered}
\mathrm{PD} \text { index }=\{[\text { total } \mathrm{PD}(\mathrm{mmol} / \mathrm{L})] / \\
\text { creatinine }(\mathrm{mmol} / \mathrm{L})\} \times \mathrm{BW}^{0.75} .
\end{gathered}
$$

The excretion of creatinine $\left(\mathrm{mmol} / \mathrm{kg}\right.$ of $\left.\mathrm{BW}^{0.75}\right)$ was extrapolated by using the estimated daily urinary volume (L) calculated from the equation by Pacheco et al. (2009). The estimated urinary creatinine excretion $\left(0.9 \mathrm{mmol} / \mathrm{kg}\right.$ of $\left.\mathrm{BW}^{0.75}\right)$ was included in the following equation to estimate the daily excretion of PD (mmol/ $\mathrm{kg}$ of $\left.\mathrm{BW}^{0.75}\right)$ :

$$
\begin{aligned}
& \text { daily excretion of PD }\left(\mathrm{dPD} ; \mathrm{mmol} / \mathrm{kg} \text { of } \mathrm{BW}^{0.75}\right)= \\
& \text { PD index } \times 0.9 .
\end{aligned}
$$

From this, the amount of purines absorbed daily was estimated: 


$$
\begin{gathered}
\text { daily absorbed purines }(\mathrm{daP})=[\mathrm{dPD} \\
\left.\left(\mathrm{mmol} / \mathrm{kg} \text { of } \mathrm{BW}^{0.75}\right)-0.385 \times \mathrm{BW}^{0.75}\right]+0.85
\end{gathered}
$$

microbial $\mathrm{N}$ ( $\mathrm{g}$ of $\mathrm{N} / \mathrm{d}$ ) supply was determined using the following equation:

$$
\begin{gathered}
\text { microbial } \mathrm{N}(\mathrm{g} \text { of } \mathrm{N} / \mathrm{d})=(\mathrm{daP} \times 70) / \\
(0.116 \times 0.83 \times 1,000)
\end{gathered}
$$

\section{Statistical Analysis and Calculations}

Treatment means were determined using data from individual measurements collected from animal samples on d 6, 8, and 10 (urine, feces, milk, and blood), whereas intakes were estimated as means for the treatment group because animals were grazed in treatment groups. No effect of treatment was observed within data collected during the baseline ( $\mathrm{d} 0$ ); hence, d 0 was excluded from the current statistical analysis. Statistical analysis of PD and associated calculations was based on the mean of values determined for urine samples collected after the morning and afternoon milkings on d 10. Treatment means for the experimental period were analyzed in GenStat (version 12; VSN International Ltd., Hemel Hempstead, UK) by one-way ANOVA, with pasture treatment (3 levels) and cow block (12 levels) as factors (Payne et al., 2009).

Total $\mathrm{N}$ intake was calculated using the $\mathrm{N}$ content (\%) of the pasture mixes and the average daily intake (kg) of the 3 treatment groups. Milk $\mathrm{N}$ output was calculated by dividing the milk protein content (\%) by 6.38 to give $\mathrm{N}(\%)$. This was then multiplied by the milk yield $(\mathrm{kg} / \mathrm{d})$ to give the total $\mathrm{N}$ output in milk. Urinary $\mathrm{N}$ excretion (g/d) was estimated using the equation urinary $\mathrm{g}$ of $\mathrm{N} / \mathrm{d}=21.9(\mathrm{mg} / \mathrm{kg}) \times \mathrm{BW}(\mathrm{kg}) \times[1 /$ urinary creatinine $(\mathrm{mg} / \mathrm{kg})] \times$ urine $\mathrm{N}(\mathrm{g} / \mathrm{kg})$, as described by Pacheco et al. (2009). Treatment effects on pasture chemical and forage composition and estimated group DMI and $\mathrm{N}$ intake were compared by ANOVA, with sampling day as the replicate. Results were declared to be significant at $P<0.05$.

\section{RESULTS}

\section{DMI and Pasture Quality}

Chemical and botanical composition of the pastures is presented in Tables 1 and 2, respectively. No difference in DMI $(P=0.84)$ was observed between pasture treatments (Table 1$)$. The HSD pasture had a lower $(P$ $<0.001) \mathrm{CP}$ content compared with the RG and HS plots; however, no difference $(P=0.33)$ in $\mathrm{N}$ intake $(\mathrm{g}$ of $\mathrm{N} / \mathrm{d}$ ) was observed. In addition, no differences $(P$ $=0.106$ ) were observed between the $\mathrm{ME}$ contents of the diets, resulting in a similar energy intake across all treatments (Table 1).

The HSD plots had a higher WSC concentration compared with the RG and HS plots. The HSD plots also had lower $\operatorname{ADF}(P=0.002)$ and NDF $(P<0.001)$ concentrations compared with the RG plots (Table 1 ). No differences were observed in the DM digestibility $(P$ $=0.158)$ of all 3 plots.

No differences were observed between the botanical composition of RG and HS $(P>0.233$; Table 2). The chicory, plantain, and lotus contents of the HSD plots were $36.1,18.4$, and $0.2 \%$ of DM, respectively. In addition, the total CT concentration of the HSD pasture was determined to be $0.2 \%$ (data not shown) based on a standard curve developed from $L$. pedunculatus.

Table 1. Diet characteristics of the 3 pasture mixes

\begin{tabular}{lcccccc}
\hline & \multicolumn{3}{c}{ Treatment $^{1}$} & & \\
\cline { 2 - 4 } Item & RG & HS & HSD & SEM & $P$-value \\
\hline Pregrazing pasture mass (kg of DM/ha) & 2,525 & 2,520 & 2,726 & 116.3 & 0.38 \\
DMI (kg/cow per day) & 14.0 & 14.5 & 14.5 & 0.65 & 0.84 \\
CP (\% of DM) & $26.2^{\mathrm{a}}$ & $26.3^{\mathrm{a}}$ & $23.7^{\mathrm{b}}$ & 0.30 & $<0.001$ \\
Dietary N intake (g/d) & 589.7 & 609.9 & 550.7 & 26.6 & 0.33 \\
DM (\%) & 15.8 & 16.7 & 14.2 & 0.72 & 0.08 \\
ME (MJ/kg of DM) & 12.3 & 12.3 & 12.2 & 0.04 & 0.11 \\
WSC (\% of DM) & $14.6^{\mathrm{a}}$ & $15.8^{\mathrm{a}}$ & $20.1^{\mathrm{b}}$ & 0.45 & $<0.001$ \\
ADF (\% of DM) & $19.5^{\mathrm{a}}$ & $18.3^{\mathrm{b}}$ & $17.8^{\mathrm{b}}$ & 0.22 & 0.002 \\
NDF (\% of DM) & $33.1^{\mathrm{a}}$ & $30.7^{\mathrm{a}}$ & $22.8^{\mathrm{b}}$ & 0.77 & $<0.001$ \\
DMD $^{3}(\%$ of DM) & 83.0 & 83.5 & 83.7 & 0.22 & 0.16 \\
\hline
\end{tabular}

${ }^{\mathrm{a}, \mathrm{b}}$ Means within a row with different superscripts differ $(P<0.05)$.

${ }^{1}$ Treatments: $\mathrm{RG}=$ ryegrass; HS = high-sugar ryegrass; HSD = high-sugar ryegrass diversity.

${ }^{2} \mathrm{WSC}=$ water-soluble carbohydrate.

${ }^{3} \mathrm{DMD}=\mathrm{DM}$ digestibility. 
Table 2. Botanical composition (\% of total DM) of the pasture mixes

\begin{tabular}{lccccc}
\hline & \multicolumn{3}{c}{ Treatment $^{1}$} & & \\
\cline { 2 - 5 } Item & RG & HS & HSD & SEM & $P$-value \\
\hline Ryegrass & 76.7 & 65.4 & 25.6 & 5.96 & 0.25 \\
White clover & 6.7 & 13.2 & 3.9 & 3.27 & 0.23 \\
Weeds & 13.7 & 18.5 & 12.2 & 4.66 & 0.51 \\
Dead material & 2.88 & 2.85 & 3.63 & 0.61 & 0.97 \\
Chicory & - & - & 36.1 & - & - \\
Plantain & - & - & 18.4 & & - \\
Lotus & - & - & 0.19 & - & - \\
\hline
\end{tabular}

${ }^{1}$ Treatments: $\mathrm{RG}=$ ryegrass; HS = high-sugar ryegrass; HSD = high-sugar ryegrass diversity.

${ }^{2} P$-values are for RG versus HS only because HSD contained additional species.

\section{Measurements of N in Plasma, Urine, Feces, and Milk}

Cows in the HSD treatment group had a lower $(P<$ 0.001) plasma urea concentration compared with those in the RG and HS treatment groups, respectively. The plasma creatinine concentration was also lower $(P=$ 0.002 ) for the cows fed HSD compared with those fed RG and HS, respectively (Table 3 ).

The cows fed HSD had lower $(P<0.001)$ urinary N content (\%) and lower urinary $\mathrm{NH}_{3}$, urea, and creatinine concentrations compared with those of the cows fed RG and HS, which were not different from each other (Table 3). The lower $\mathrm{N}$ concentration in urine collected from cows fed HSD was reflected in a calculated $17.1 \%$ reduction in urinary $\mathrm{N}$ excretion $(\mathrm{g}$ of $\mathrm{N} / \mathrm{d}$ ) compared with that of cows fed HS and an even greater (19.3\%) reduction compared with that of cows fed RG (Table 3). Cows fed HS had a lower fecal percentage of
$\mathrm{N}(P=0.001$; Table 3$)$ compared with the cows fed RG and HSD.

Milk urea $\mathrm{N}$ concentration was affected $(P<0.001)$ by treatment (Table 3). Milk urea $\mathrm{N}$ concentration of samples collected from cows fed HS was the highest, followed by cows fed RG, and was lowest in cows fed HSD. Nitrogen excretion in milk was highest $(P=0.003)$ for cows fed HSD, at $112.1 \mathrm{~g} / \mathrm{d}$ (Table 3 ). This was $10.2 \%$ higher than that from cows fed HS $(101.8 \mathrm{~g} / \mathrm{d})$ and $7.1 \%$ higher than that from cows fed RG $(104.8 \mathrm{~g} / \mathrm{d})$.

\section{Milk Production and Composition}

Milk yield was greatest from cows on HSD pastures, at $16.9 \mathrm{~kg} / \mathrm{d}(P=0.002$; Table 4$)$. No differences $(P$ $=0.330$ ) were observed between the milk solids (milk fat + protein) yields of all 3 treatments (Table 4 ).

Table 3. Nitrogen parameters pertaining to partitioning in plasma, urine, feces, and milk of cows grazing different pasture mixes

\begin{tabular}{|c|c|c|c|c|c|}
\hline \multirow[b]{2}{*}{ Item } & \multicolumn{3}{|c|}{ Treatment $^{1}$} & \multirow[b]{2}{*}{ SEM } & \multirow[b]{2}{*}{$P$-value } \\
\hline & RG & HS & HSD & & \\
\hline \multicolumn{6}{|l|}{ Plasma } \\
\hline Urea $(\mathrm{mmol} / \mathrm{L})$ & $10.6^{\mathrm{a}}$ & $10.7^{\mathrm{a}}$ & $8.5^{\mathrm{b}}$ & 0.21 & $<0.001$ \\
\hline Creatinine $(\mu \mathrm{mol} / \mathrm{L})$ & $58.6^{\mathrm{a}}$ & $59.5^{\mathrm{a}}$ & $53.4^{\mathrm{b}}$ & 1.23 & 0.002 \\
\hline \multicolumn{6}{|l|}{ Urine } \\
\hline $\mathrm{N}(\%)$ & $0.57^{\mathrm{a}}$ & $0.58^{\mathrm{a}}$ & $0.34^{\mathrm{b}}$ & 0.02 & $<0.001$ \\
\hline $\mathrm{NH}_{3}(\mathrm{mmol} / \mathrm{L})$ & $0.66^{\mathrm{a}}$ & $0.75^{\mathrm{a}}$ & $0.36^{\mathrm{b}}$ & 0.06 & $<0.001$ \\
\hline Urea $(\mathrm{mmol} / \mathrm{L})$ & $177.6^{\mathrm{a}}$ & $180.4^{\mathrm{a}}$ & $103.5^{\mathrm{b}}$ & 6.63 & $<0.001$ \\
\hline Creatinine $(\mathrm{mmol} / \mathrm{L})$ & $1.2^{\mathrm{a}}$ & $1.2^{\mathrm{a}}$ & $0.88^{\mathrm{b}}$ & 0.05 & $<0.001$ \\
\hline $\mathrm{N}$ output $(\mathrm{g} / \mathrm{d})$ & $438.3^{\mathrm{a}}$ & $426.6^{\mathrm{a}}$ & $353.8^{\mathrm{b}}$ & 12.0 & $<0.001$ \\
\hline \multicolumn{6}{|l|}{ Feces } \\
\hline N (\%) & $3.6^{\mathrm{a}}$ & $3.4^{\mathrm{b}}$ & $3.5^{\mathrm{a}}$ & 0.04 & 0.001 \\
\hline Ash (\%) & $25.3^{\mathrm{a}}$ & $26.5^{\mathrm{a}}$ & $30.4^{\mathrm{b}}$ & 0.47 & $<0.001$ \\
\hline DM $(\%)$ & 10.7 & 11.5 & 11.2 & 0.33 & 0.20 \\
\hline \multicolumn{6}{|l|}{ Milk } \\
\hline Urea N (mmol/L) & $11.4^{\mathrm{a}}$ & $12.1^{\mathrm{b}}$ & $9.5^{\mathrm{c}}$ & 0.22 & $<0.001$ \\
\hline $\mathrm{N}$ excretion $(\mathrm{g} / \mathrm{d})$ & $104.8^{\mathrm{a}}$ & $101.8^{\mathrm{a}}$ & $112.1^{\mathrm{b}}$ & 1.93 & 0.003 \\
\hline
\end{tabular}


TOTTY ET AL.

Table 4. Milk production and composition of cows grazing different pasture mixes

\begin{tabular}{lccccc}
\hline & \multicolumn{3}{c}{ Treatment $^{1}$} \\
\cline { 2 - 4 } Item & RG & HS & HSD & SEM & P-value \\
\hline Milk yield (L/d) & $15.2^{\mathrm{a}}$ & $14.7^{\mathrm{a}}$ & $16.9^{\mathrm{b}}$ & 0.41 & 0.002 \\
Milk solids (kg/d) & 1.55 & 1.49 & 1.47 & 0.03 & 0.33 \\
Milk fat (\%) & $6.1^{\mathrm{a}}$ & $6.1^{\mathrm{a}}$ & $5.0^{\mathrm{b}}$ & 0.18 & $<0.001$ \\
Milk fat (g/d) & 920 & 869 & 819 & 27.7 & 0.056 \\
Milk protein (\%) & $4.1^{\mathrm{ab}}$ & $4.2^{\mathrm{a}}$ & $3.9^{\mathrm{b}}$ & 0.09 & 0.090 \\
Milk protein (g/d) & 628 & 616 & 655 & 11.1 & 0.061 \\
Milk lactose (\%) & $4.8^{\mathrm{a}}$ & $5.0^{\mathrm{b}}$ & $5.0^{\mathrm{b}}$ & 0.02 & $<0.001$ \\
\hline
\end{tabular}

${ }^{a, b}$ Means within a row with different superscripts differ $(P<0.05)$.

${ }^{1}$ Treatments: $\mathrm{RG}=$ ryegrass; HS = high-sugar ryegrass; HSD = high-sugar ryegrass diversity.

However, cows fed HSD produced a lower $(P<0.001)$ milk fat percentage compared with those of the RG and HS groups. The cows fed HS and HSD had different $(P=0.004)$ milk protein contents, of 4.2 and $3.9 \%$ respectively. The cows fed HSD produced the greatest milk protein yield $(P=0.061)$ compared with those in both the RG and HS groups. Milk lactose content $(\%)$ was lowest $(P<0.001)$ from cows fed RG, with no significant difference between animals fed HS and HSD (Table 4).

\section{Microbial Protein Supply}

Urinary PD concentrations, and calculations associated with estimates of microbial $\mathrm{N}$ supply are presented in Table 5. Although the urinary concentration of allantoin $(P=0.021)$ and total PD $(P=0.022)$ was lower in urine samples collected from cows grazing HSD pastures, the calculated total microbial $\mathrm{N}$ supply was not different $(P=0.678)$ across treatments.

\section{DISCUSSION}

\section{Milk Production}

The current study examined the effects of using a high-sugar grass and a diverse pasture mix on productivity and $\mathrm{N}$ partitioning in the dairy cow. The high-sugar trait was not expressed; consequently, milk parameters and $\mathrm{N}$ excretion were similar for the 2 ryegrass-based treatments. Research is limited in support of the suggestion that high WSC in perennial ryegrass cultivars can increase milk production (Edwards et al., 2007b). In European studies, higher milk yields from dairy cows have been reported when comparing cows grazing a high-WSC ryegrass compared with a control perennial ryegrass (Miller et al., 2001). However, grazing studies carried out in New Zealand have failed to show differences in milk yield on high-sugar grasses as a direct result of higher WSC concentrations (Cosgrove et al., 2007).

Table 5. Urinary concentrations of purine derivatives (PD) from cows grazing different pasture mixes

\begin{tabular}{|c|c|c|c|c|c|}
\hline \multirow[b]{2}{*}{ Purine derivative } & \multicolumn{3}{|c|}{ Treatment $^{1}$} & \multirow[b]{2}{*}{ SEM } & \multirow[b]{2}{*}{$P$-value } \\
\hline & RG & HS & HSD & & \\
\hline Allantoin $(\mathrm{mmol} / \mathrm{L})$ & $5.26^{\mathrm{b}}$ & $4.93^{\mathrm{ab}}$ & $3.55^{\mathrm{a}}$ & 0.419 & 0.021 \\
\hline Uric acid $(\mathrm{mmol} / \mathrm{L})$ & 0.26 & 0.23 & 0.25 & 0.014 & 0.49 \\
\hline Total $\mathrm{PD}^{2}(\mathrm{mmol} / \mathrm{L})$ & $5.52^{\mathrm{b}}$ & $5.17^{\mathrm{ab}}$ & $3.81^{\mathrm{a}}$ & 0.422 & 0.022 \\
\hline Allantoin:creatinine & 3.766 & 3.639 & 3.616 & 0.167 & 0.79 \\
\hline (Allantoin + uric)/creatinine & 3.96 & 3.82 & 3.88 & 0.17 & 0.85 \\
\hline PD index ${ }^{3}$ & 403.1 & 383.2 & 402.3 & 15.43 & 0.59 \\
\hline Microbial $^{4}(\mathrm{~g}$ of N/d) & 223.3 & 211.8 & 218.0 & 9.10 & 0.68 \\
\hline \multicolumn{6}{|c|}{$\overline{\mathrm{a}, \mathrm{b}}$ Means within a row with different superscripts differ $(P<0.05)$. } \\
\hline \multirow{2}{*}{\multicolumn{6}{|c|}{$\begin{array}{l}{ }^{1} \text { Treatments: } \mathrm{RG}=\text { ryegrass; HS = high-sugar ryegrass; HSD = high-sugar ryegrass diversity. } \\
{ }^{2} \text { Total PD = allantoin + uric acid. }\end{array}$}} \\
\hline & \multicolumn{5}{|c|}{${ }^{2}$ Total PD $=$ allantoin + uric acid. } \\
\hline \multicolumn{6}{|c|}{${ }^{3} \mathrm{PD}$ index $=[($ total $\mathrm{PD}) /$ creatinine $] \times \mathrm{BW}^{0.75}(\mathrm{~kg})$} \\
\hline \multicolumn{6}{|c|}{$\begin{array}{l}{ }^{4} \text { Determined assuming daily purine derivative excretion }\left(\mathrm{dPD} ; \mathrm{mmol} / \mathrm{kg} \text { of } \mathrm{BW}^{0.75}\right)=\mathrm{PD} \text { index } \times 0.9 \text {; daily } \\
\text { absorbed purines }(\mathrm{daP})=\left[\mathrm{dPD}\left(\mathrm{mmol} / \mathrm{kg} \text { of } \mathrm{BW}^{0.75}\right)-0.385 \times \mathrm{BW}^{0.75}\right]+0.85 ; \text { and microbial } \mathrm{N}(\mathrm{g} \text { of N} / \mathrm{d}) \\
=(\mathrm{daP} \times 70) /(0.116 \times 0.83 \times 1,000)\end{array}$} \\
\hline
\end{tabular}


In contrast, cows offered a diverse pasture produced $2.0 \mathrm{~L}$ of milk/cow per day more than cows on ryegrassbased pastures. However, cows on HSD produced $33 \mathrm{~g}$ of milk protein/cow per day more and $76 \mathrm{~g}$ of milk fat/ cow per day less than those on ryegrass, resulting in similar milk solids production. The current results comparing simple and diverse pastures support observations made by Soder et al. (2006), who showed that a mix of chicory and several species of grasses and legumes did not increase DMI or milk production. However, in the study by Soder et al. (2006), the supplementation of pasture diet with $40 \%$ concentrates was likely to veil the potential benefits of altering nutrient supply in mixed-species pasture diets.

A number of grazing studies have compared animal performance on diverse and simple pastures and have shown benefits from the inclusion of herbs (Chapman et al., 2008; Hutton et al., 2011). However, these studies were carried out during midlactation, when energy demands were high and responses to diet were largely attributed to differences in herbage quality affecting intake. In the current study, the RG and HS pastures had very similar chemical composition, including carbohydrate content, which resulted in few differences between animal parameters. Inclusion of chicory and plantain with high-sugar ryegrass created a diet similar to ryegrass-based mixes with respect to digestibility and energy content but varying in water, carbohydrate, and protein. Pasture treatments were offered at the same allowance during late lactation, when energy demands for milk are declining. Thus, the slight response to diet treatments in terms of milk solids production could be expected because no differences were observed in apparent ME intake.

\section{N Partitioning}

Although an increase in total milk solids was not observed on the diverse pasture, clear benefits were seen in terms of urinary $\mathrm{N}$ excretion. Offering dairy cows a pasture mix containing herbs reduced the urinary $\mathrm{N}$ concentration by almost half. Previous studies have shown the excretion of $\mathrm{N}$ in urine to be linearly related to $\mathrm{N}$ intake (Tas et al., 2006; Hoekstra et al., 2007; Higgs et al., 2012). Although the HSD pasture itself provided a lower $\mathrm{N}$ diet, the differences in dietary $\mathrm{N}$ intake between the treatments did not fully explain the $\mathrm{N}$ excretion results found in this trial. Decreased urinary $\mathrm{N}$ output and increased milk $\mathrm{N}$ output, under reduced $\mathrm{N}$ intake, suggest that $\mathrm{N}$ partitioning had been altered in cows on HSD. Although $\mathrm{N}$ intake was not statistically different between treatments, pasture diets were different in $\mathrm{N}$ content and at similar DMI. It could be argued that differences in $\mathrm{N}$ intake are biologically meaningful. The large reduction in urinary $\mathrm{N}$ and trend for increased milk protein on the diverse diet indicate the value of reductions in $\mathrm{N}$ intake of as little as $50 \mathrm{~g}$ of $\mathrm{N} / \mathrm{d}$ or $8 \%$ of $\mathrm{N}$ intake. Aside from reduced $\mathrm{N}$ intake, the 2 factors that may have contributed to a change in partitioning are (1) the ratio of WSC and CP and (2) the possibility of bioactivity of the secondary plant compounds known to exist in herbs.

It was predicted that the HSD plots would contain higher concentrations of $\mathrm{CT}$ compared with the RG and HS pastures and would potentially contribute to this shift in urinary and fecal N. However, only a trace amount of $\mathrm{CT}$ was detected in pasture samples collected from the HSD plots, which may be due to the standard curve used for analysis being based on L. pedunculatus. The CT previously observed in chicory (range of 1.7 to $4.2 \mathrm{~g}$ of CT $/ \mathrm{kg}$ of DM; Jackson et al., 1996; Barry and McNabb, 1999) and plantain (approximately $14 \mathrm{~g}$ of CT/kg of DM; Jackson et al., 1996; Ramirez-Restrepo and Barry, 2005) could have molecular structures sufficiently different from the CT present in L. pedunculatus to prevent detection in the assay used (Schofield et al., 2001). Identification of the $\mathrm{CT}$ isomers present in the HSD pastures and their astringency is required to determine the potential for it to affect protein availability in the ruminant gastrointestinal tract (Waghorn, 2008). The higher milk protein secretion, low urinary $\mathrm{N}$, and similar fecal $\mathrm{N}$ attained in HSD treatments support the hypothesis that herbs increased the proportion of digestible RUP. The term CT is used to describe a wide range of proanthocyanidins with complex structures that have proven difficult both to measure and to describe in terms of their bioactivity (Schofield et al., 2001). In addition to CT, plantain contains several secondary plant compounds, including iridoid glycosides (Tamura and Nishibe, 2002). Several effects arise from the bioactivity of secondary compounds, including diuretic and laxative effects (Stewart, 1996). Although difficult to ascertain, the influence of the large differences in mineral and metabolite composition on urinary $\mathrm{N}$ dilution cannot be disregarded.

An alternative explanation for differences in urinary $\mathrm{N}$ excretion between treatments was changes in the WSC:CP ratio. The higher WSC content of the HSD pasture along with the lower $\mathrm{CP}$ content may improve the supply of energy and protein to meet microbial requirements. A WSC:CP ratio of greater than 0.7 can lead to a reduction in the proportion of $\mathrm{N}$ intake excreted in urine and an increase in $\mathrm{N}$ intake excreted in milk (Edwards et al., 2007a). Our trial achieved a WSC:CP ratio of 0.85 in the HSD plots compared with 0.58 in the RG and HS treatments; the relative differ- 
ence in urinary percentage of $\mathrm{N}$ supports conclusions made by Edwards et al. (2007a). Another indication of improvements in energy and protein supply to rumen is the PD index, which is a relative measure of intestinal microbial protein supply (Chen et al., 1995). However, in spite of seemingly large differences in the ratio of WSC:CP, the lack of difference in the PD index indicates similar levels of microbial activity between the treatments. Thus, the WSC:CP ratio may reduce $\mathrm{N}$ secretion in the urine, but this effect appears to be more closely linked with lower total $\mathrm{N}$ intake rather than improving the synchrony of energy with CP supplied to the rumen per se.

\section{CONCLUSIONS}

Our results demonstrate a role for the use of high-diversity pastures containing herbs as a mitigation strategy to reduce the environmental impact of dairying. Although the exact mechanisms inducing the marked reduction in urinary $\mathrm{N}$ are yet to be fully understood, the results showed no disadvantage to milk production on diverse pastures in late lactation. Current use of high-N-containing ryegrass and clover pastures ultimately results in providing excess $\mathrm{N}$ to dairy cows, and subsequently large $\mathrm{N}$ losses in urine as a metabolic cost and waste. By providing a diverse pasture, a significant reduction in urinary $\mathrm{N}$ losses can be achieved, thus providing an environmental benefit.

\section{REFERENCES}

AOAC (Association of Official Analytical Chemists). 1990. Official Methods of Analysis. Assoc. Off. Anal. Chem., Arlington, VA.

Barry, T. N., and W. C. McNabb. 1999. The implications of condensed tannins on the nutritive value of temperate forages fed to ruminants. Br. J. Nutr. 81:263-272.

Bartels, H., and M. Böhmer. 1971. Micro-determination of creatinine. Clin. Chim. Acta 32:81-85.

Chapman, D. F., J. Tharmaraj, and Z. N. Nie. 2008. Milk-production potential of different sward types in a temperate southern Australian environment. Grass Forage Sci. 63:221-233.

Chen, X. B. 1989. Excretion of purine derivatives by sheep and cattle and its use for the estimation of absorbed microbial protein. $\mathrm{PhD}$ Thesis. Univ. of Aberdeen, Aberdeen, Scotland

Chen, X. B., P. Susmel, B. Stefanon, and E. R. Ørskov. 1995. Protein metabolism and nutrition. Pages 325-329 in Proc. 7th Int. Symp. Protein Metab. Nutr., Vale de Santarem, Portugal.

Cosgrove, G. P., J. L. Burke, A. F. Death, M. J. Hickey, D. Pacheco, and G. A. Lane. 2007. Ryegrasses with increased water soluble carbohydrate: Evaluating the potential for grazing dairy cows in New Zealand. Proc. N. Z. Grassl. Assoc. 69:179-185.

Czauderna, M., and J. Kowalczyk. 2000. Quantification of allantoin, uric acid, xanthine and hypoxanthine in ovine urine by high-performance liquid chromatography and photodiode array detection. J. Chromatogr. B Biomed. Sci. Appl. 744:129-138.

Di, H. J., and K. C. Cameron. 2002. Nitrate leaching in temperate agroecosystems: Sources, factors and mitigating strategies. Nutr. Cycl. Agroecosyst. 64:237-256.
Edwards, G. R., A. J. Parsons, and S. Rasmussen. 2007a. High sugar ryegrasses for dairy systems. Pages 307-334 in Meeting the Challenges for Pasture-Based Dairying. Natl. Dairy Alliance, Melbourne, Australia.

Edwards, G. R., A. J. Parsons, S. Rasmussen, and R. H. Bryant 2007b. High sugar ryegrasses for livestock systems in New Zealand. Proc. N. Z. Grassl. Assoc. 69:161-171.

George, S. K., M. T. Dipu, U. R. Mehra, P. Singh, A. K. Verma, and J. S. Rangaokar. 2006. Improved HPLC method for the simultaneous determination of allantoin, uric acid and creatinine in cattle urine. J. Chromatogr. B Analyt. Technol. Biomed. Life Sci. 832:134-137.

Haynes, R. J., and P. H. Williams. 1993. Nutrient cycling and soil fertility in the grazed pasture ecosystem. Adv. Agron. 49:119-199.

Higgs, R. J., L. E. Chase, and M. E. van Amburgh. 2012. Development and evaluation of equations in the Cornell Net Carbohydrate and Protein System to predict nitrogen excretion in lactating dairy cows. J. Dairy Sci. 95:2004-2014.

Hoekstra, N. J., R. P. O. Schulte, P. C. Struik, and E. A. Lantinga. 2007. Pathways to improving the $\mathrm{N}$ efficiency of grazing bovines. Eur. J. Agron. 26:363-374

Hutton, P. G., P. R. Kenyon, M. K. Bedi, P. D. Kemp, K. J. Stafford, D. M. West, and S. T. Morris. 2011. A herb and legume sward mix increased milk production and ewe and lamb live weight gain to weaning compared to a ryegrass dominant sward. Anim. Feed Sci. Technol. 164:1-7.

Iowerth, D., H. Jones, and M. V. Hayward. 1975. The effect of pepsin pretreatment of herbage on the prediction of dry matter digestibility from solubility in fungal cellulase solutions. J. Sci. Food Agric. 26:711-718.

Jackson, F. S., T. N. Barry, C. Lascano, and B. Palmer. 1996. The extractable and bound condensed tannin content of leaves from tropical tree, shrub and forage legumes. J. Sci. Food Agric. $71: 103-110$

Joint FAO/IAEA Division. 2003. Training package. The technique for the estimation of microbial $\mathrm{N}$ supply in ruminants from purine derivatives in urine. Accessed Sep. 22, 2012. http://www.iaea.org/ nafa/aph/purine-cd/html/about/index.html.

MAFF (Ministry of Agriculture, Fisheries and Food). 1986. Carbohydrates, soluble, in herbage. Pages 43-45 in The Analysis of Agricultural Materials. 3rd ed. Her Majesty's Stationery Office, London, UK.

Miller, L. A., J. M. Moorby, D. R. Davies, M. O. Humphreys, N. D. Scollan, J. C. MacRae, and M. K. Theodorou. 2001. Increased concentration of water-soluble carbohydrate in perennial ryegrass (Lolium perenne): Milk production from late-lactation dairy cows. Grass Forage Sci. 56:383-394.

Moorby, J. M., R. T. Evans, N. D. Scollan, J. C. MacRae, and M. K. Theodorou. 2006. Increased concentration of water-soluble carbohydrate in perennial ryegrass (Lolium perenne L.). Evaluation in dairy cows in early lactation. Grass Forage Sci. 61:52-59.

Pacheco, D., K. Lowe, J. L. Burke, and G. P. Cosgrove. 2009. Urinary nitrogen excretion from cows at different stage of lactation grazing different ryegrass cultivars during spring or autumn. Proc. N. Z. Soc. Anim. Prod. 69:196-200.

Payne, R., D. Murray, S. Harding, D. Baird, and D. Soutar. 2009. Introduction. GenStat. 12th ed. Accessed Sep. 22, 2012. http://www. vsni.co.uk/downloads/genstat/release12/doc/IntroGuide.pdf.

Powell, J. M., G. A. Broderick, J. H. Grabber, and U. C. Hymes-Fecht 2009. Effects of forage protein-binding polyphenols on chemistry of dairy excreta. J. Dairy Sci. 92:1765-1769.

Ramirez-Restrepo, C. A., and T. N. Barry. 2005. Alternative temperate forages containing secondary compounds for improving sustainable productivity in grazing ruminants. Anim. Feed Sci. Technol. 120:179-201.

Schofield, P., D. M. Mbugua, and A. N. Pell. 2001. Analysis of condensed tannins: A review. Anim. Feed Sci. Technol. 91:21-40.

Soder, K. J., M. A. Sanderson, J. L. Stack, and L. D. Muller. 2006. Intake and performance of lactating cows grazing diverse forage mixtures. J. Dairy Sci. 89:2158-2167. 
Stewart, A. V. 1996. Plantain (Plantago lanceolata) - A potential pasture species. Proc. N. Z. Grassl. Assoc. 58:77-86.

Talke, H., and G. E. Schubert. 1965. Enzymatische Harnstoffbestimmung in Blut und Serum im optischen Test nach Warburg. J. Mol. Med. 43:174-175.

Tamura, Y., and S. Nishibe. 2002. Changes in the concentrations of bioactive compounds in plantain leaves. J. Agric. Food Chem. 50:2514-2518.

Tas, B. M., H. Z. Taweel, H. J. Smit, A. Elgersma, J. Dijkstra, and S. Tamminga. 2006. Effects of perennial ryegrass cultivars on milk yield and nitrogen utilization in grazing dairy cows. J. Dairy Sci. 89:3494-3500.

Terrill, T. H., A. M. Rowan, G. B. Douglas, and T. N. Barry. 1992 Determination of extractable and bound condensed tannin concentrations in forage plants, protein concentrate meals and cereal grains. J. Sci. Food Agric. 58:321-329.

Van Soest, P. J. 1991. Methods for dietary fiber, neutral detergent fiber and nonstarch polysaccharides in relation to animal nutrition. J. Dairy Sci. 74:3583-3597.

Verbic, J., X. B. Chen, N. A. Macleod, and E. R. Ørskov. 1990. Excretion of purine derivatives by ruminants. Effect of microbial nucleic acid infusion on purine derivative excretion by steers. J. Agric. Sci. Camb. 114:243-248.

Waghorn, G. 2008. Beneficial and detrimental effects of dietary condensed tannins for sustainable sheep and goat production-Progress and challenges. Anim. Feed Sci. Technol. 147:116-139.

Waghorn, G. C., J. L. Burke, and E. S. Kolver. 2007. Principles of feeding value. Pages 35-60 in Pastures and Supplements for Grazing Animals. P. V. Rattray, I. M. Brookes, and A. M. Nicol, ed. New Zealand Society of Animal Production. Occasional Publication Number 14, Hamilton, New Zealand.

Waghorn, G. C., I. D. Shelton, W. C. McNabb, and S. N. McCutcheon, 1994. Effects of condensed tannins in Lotus pedunculatus on its nutritive value for sheep. 2. Nitrogenous aspects. J. Agric. Sci. 123:109-119.

Woodward, S. L., G. G. Waghorn, K. A. Watkins, and M. A. Bryant. 2009. Feeding birdsfoot trefoil (Lotus corniculatus) reduces the environmental impacts of dairy farming. Proc. N. Z. Soc. Anim. Prod. 69:179-183. 